\title{
Stent Placement for Malignant Inferior Vena Cava Syndrome in a Patient with Recurrent Colon Cancer
}

\author{
Shinichi Morita ${ }^{1}$, Shunsuke Sugawara ${ }^{2}$, Takeshi Suda ${ }^{1}$, Didik Prasetyo ${ }^{1}$, Yuka Kobayashi ${ }^{3}$, \\ Takahiro Hoshi ${ }^{1}$, Satoshi Abe ${ }^{1}$, Kazuyoshi Yagi ${ }^{1}$ and Shuji Terai ${ }^{4}$
}

\begin{abstract}
:
A 70-year-old man was admitted to our hospital with gait disturbance due to marked edema of the lower limbs for more than 6 months. He had been receiving systemic chemotherapy over two years for multiple recurrence after sigmoid colon cancer resection. Contrast-enhanced computed tomography demonstrated severe inferior vena cava (IVC) stenosis due to compression by lymph node metastases, i.e. IVC syndrome. As increased doses of diuretic agents failed to improve the edema, IVC stent placement was performed. This led to significant improvement of the edema and complete gait normalization. This case demonstrates the efficacy of IVC stent placement for IVC syndrome.
\end{abstract}

Key words: inferior vena cava syndrome, IVC stent, stent placement, colon cancer, quality of life

(Intern Med 59: 2885-2890, 2020)

(DOI: 10.2169/internalmedicine.5033-20)

\section{Introduction}

Vena cava syndrome is a complication of malignant tumor progression (1-3). Enlarged tumors disturb the venous return by compressing the vena cava, causing various symptoms. Lung or mediastinal tumors may cause superior vena cava (SVC) stenosis; this results in SVC syndrome, with edema of the chest, upper limbs, head, and neck, followed by respiratory and central nervous symptoms, which can sometimes be fatal and therefore require immediate treatment $(2,4-6)$. Liver and retroperitoneal tumors, by contrast, can cause inferior vena cava (IVC) stenosis and IVC syndrome, with lower limb edema and intractable ascites (7-9). This causes lower limb pain, abdominal bloating, and gait disturbance. However, IVC syndrome is only rarely fatal, and many patients are followed up with conservative treatment with only minimal improvement of symptoms. As a result, the quality of life (QOL) is significantly impaired.

In recent years, several reports have indicated that percutaneous stent placement in the stenotic area can achieve a rapid and effective therapeutic effect for vena cava syn- drome (10-14). We herein report a case of IVC syndrome caused by lymph node metastases from recurrent colon cancer. The patient had been suffering from severe lower limb edema for more than six months, but the symptoms were significantly improved by IVC stent placement.

\section{Case Report}

A 70-year-old Japanese man was referred to our hospital with a complaint of marked lower limb edema and gait disturbance. He had undergone laparoscopic partial resection for sigmoid colon cancer at a referral hospital three years earlier. Utilizing the Union for International Cancer Control TNM classification (8th edition) (15), the tumor of the sigmoid colon was classified as pT3NOM0, Stage IIA. A year later, multiple recurrences of liver and para-aortic lymph node metastases were noted, necessitating continuation of systemic chemotherapy. Lower limb edema had appeared six months earlier. Despite diuretic therapy, his lower limb edema had worsened, and his body weight had increased by more than $10 \mathrm{~kg}$. He had difficulty walking due to edema in both legs, and urination had become difficult due to marked

\footnotetext{
${ }^{1}$ Department of Gastroenterology and Hepatology, Uonuma Institute of Community Medicine Niigata University Hospital, Japan, ${ }^{2}$ Department of Diagnostic Radiology, National Cancer Center Hospital, Japan, ${ }^{3}$ Department of Gastroenterology and Hepatology, Nagaoka Central General Hospital, Japan and ${ }^{4}$ Division of Gastroenterology and Hepatology, Graduate School of Medical and Dental Sciences, Niigata University, Japan Received: April 6, 2020; Accepted: June 11, 2020; Advance Publication by J-STAGE: July 28, 2020 Correspondence to Dr. Shinichi Morita, m0riz0u@extra.ocn.ne.jp
} 


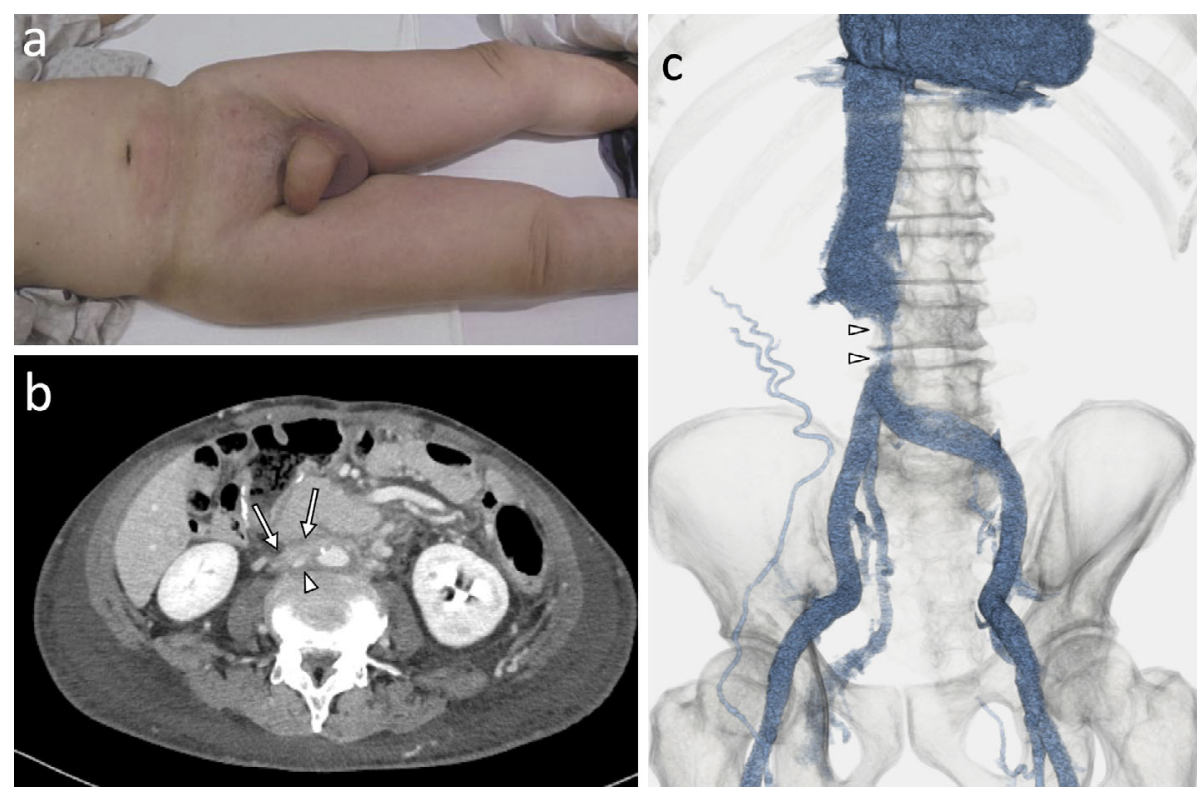

Figure 1. (a) Photograph before IVC stent placement showing severe hydrocele testis and bilateral leg edema. (b) Axial abdominal contrast-enhanced CT image showing the IVC surrounded by lymph node metastases (arrow), causing stenosis (arrowheads). (c) CT reconstruction venography showing severe stenosis of the IVC about $3 \mathrm{~cm}$ cranial from the confluence of the left and right common iliac veins (arrowheads).

Table 1. Laboratory Data on Admission.

\begin{tabular}{lclclc}
\hline Hematologic test & & Coagulation & & BUN & $16.1 \mathrm{mg} / \mathrm{dL}$ \\
White blood cells & $5,100 / \mu \mathrm{L}$ & PT-INR & 0.92 & Creatinine & $1.1 \mathrm{mg} / \mathrm{dL}$ \\
Neutrophils & $82.9 \%$ & APTT & $27.9 \mathrm{~s}$ & Sodium & $142 \mathrm{mmol} / \mathrm{L}$ \\
Lymphocytes & $9.9 \%$ & D-dimer & $0.8 \mu \mathrm{g} / \mathrm{mL}$ & Potassium & $3.8 \mathrm{mmol} / \mathrm{L}$ \\
Monocytes & $6.4 \%$ & & Chloride & $105 \mathrm{mmol} / \mathrm{L}$ \\
Eosinophils & $0.6 \%$ & Chemistry & & CRP & $0.54 \mathrm{mg} / \mathrm{dL}$ \\
Basophils & $0.2 \%$ & Total protein & $6.9 \mathrm{~g} / \mathrm{dL}$ & BNP & $16.5 \mathrm{pg} / \mathrm{mL}$ \\
Red blood cells & $295 \times 10^{4} / \mu \mathrm{L}$ & Albumin & $3.9 \mathrm{~g} / \mathrm{dL}$ & CEA & $53.6 \mathrm{ng} / \mathrm{mL}$ \\
Hemoglobin & $10.0 \mathrm{~g} / \mathrm{dL}$ & AST & $25 \mathrm{IU} / \mathrm{L}$ & CA19-9 & $16.0 \mathrm{U} / \mathrm{mL}$ \\
Platelet count & $26.6 \times 10^{4} / \mu \mathrm{L}$ & ALT & $27 \mathrm{IU} / \mathrm{L}$ & & \\
& & ALP & $397 \mathrm{IU} / \mathrm{L}$ & Urine test & \\
& & $\gamma-G T P$ & $121 \mathrm{IU} / \mathrm{L}$ & Occult blood & negative \\
& & T.Bil & $0.9 \mathrm{mg} / \mathrm{dL}$ & Glycosuria & negative \\
& & D.Bil & $0.1 \mathrm{mg} / \mathrm{dL}$ & Proteinuria & negative \\
& & LDH & $158 \mathrm{IU} / \mathrm{L}$ & & \\
\hline
\end{tabular}

PT: prothrombin time activity, APTT: activated partial thromboplastin time, AST: aspartate aminotransferase, ALT: alanine aminotransferase, ALP: alkaline phosphatase, $\gamma$-GTP: $\gamma$-glutamyl transpeptidase, T.Bil: total bilirubin, D.Bil: direct bilirubin, LDH: lactate dehydrogenase, BUN: blood urea nitrogen, CRP: C-reactive protein, BNP: brain natriuretic peptide, CEA: carcinoembryonic antigen, CA19-9: carbohydrate antigen 19-9

scrotal edema (Fig. 1a). Based on these symptoms, the patient's Eastern Cooperative Oncology Group Performance Status Grade had decreased from one to three, so systemic chemotherapy had been discontinued.

On presentation, the patient's body weight was $64 \mathrm{~kg}$, and marked pitting edema was evident in the lower limbs, but not the upper limbs. Biochemical tests revealed no abnormalities of the liver or renal function, and the serum albumin level was not decreased. His blood coagulation remained within normal limits, and a urinalysis was negative for proteinuria (Table 1). Electrocardiography and chest Xray revealed no abnormalities. Contrast-enhanced computed tomography (CT) demonstrated para-aortic lymph node metastases around the IVC, with compression and stenosis (Fig. 1b). The IVC was stenotic about $3 \mathrm{~cm}$ cranially from the confluence of the left and right common iliac veins (Fig. 1c). However, the stenosis did not reach the hepatic portion of the IVC. The right renal vein joined normally with the IVC, while the left renal vein was obstructed by the tumor. No thrombus was found in the IVC distal from 
the stenotic site. IVC syndrome was diagnosed, and IVC stent placement was recommended.

With informed consent from the patient, IVC venography was performed via the right femoral vein approach. A 3-cmlong stenosis was found with the retrograde visualization of collateral veins, such as the ascending lumbar, azygos and hemiazygos veins (Fig. 2a). A guidewire was passed through the stenosis, and a stent delivery system was inserted beyond the site. A self-expandable metallic bare stent, $18 \mathrm{~mm}$ in diameter and $60 \mathrm{~mm}$ in length (Spiral relief stent; COS-

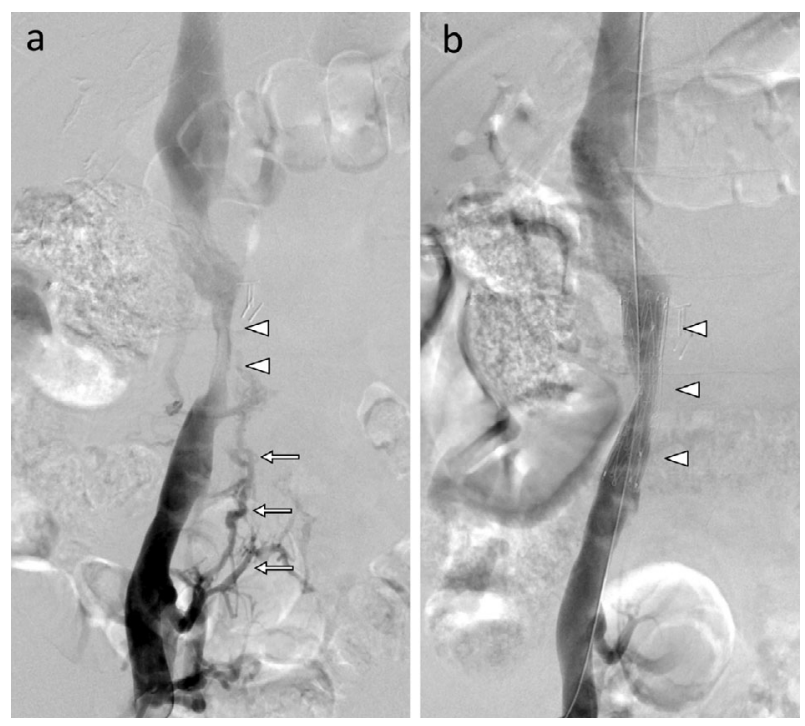

Figure 2. (a) Digital subtraction venography showing severe stenosis of the IVC (arrowheads) and retrograde visualization of collateral veins, such as the ascending lumbar, azygos and hemiazygos veins (arrows). (b) Digital subtraction venography after stent placement (arrowheads) demonstrating improvement of flow in the IVC and disappearance of collateral veins.
MOTEC, Tokyo, Japan), was placed across the stenotic site. Venography was then performed to confirm the improvement of flow in the IVC and disappearance of the collateral veins (Fig. 2b). No adverse events were observed during the procedure. A direct oral anticoagulant (edoxaban tosilate hydrate $5 \mathrm{mg}$ /day) was provided from the next day to prevent thrombus formation in the stent. After stent placement, the urine output increased, and the thigh edema began to lessen. One week after the treatment, the bilateral leg edema was markedly reduced, and the average circumference of both the thighs and calves was reduced from 51.6 to $42.5 \mathrm{~cm}$ and 40.4 to $33.5 \mathrm{~cm}$, respectively (Fig. 3). The patient's body weight decreased by $14 \mathrm{~kg}$, along with disappearance of the scrotal edema. Furthermore, a normal gait returned without any issues. One month later, systemic chemotherapy was resumed. Seven months after stent placement, there were no stent-related complications, the edema had not recurred, and chemotherapy was able to be continued.

\section{Discussion}

Edema is a symptom that reduces the QOL of cancer patients but does not significantly affect the disease prognosis. However, patients suffer gait disturbance and discomfort in the areas affected by edema. There are various causes and conditions responsible for edema, and their understanding is clinically useful $(16,17)$. Edema can be either systemic or local, with the former arising due to systemic conditions, such as renal dysfunction, congestive heart failure, liver cirrhosis, hypothyroidism, malnutrition and the side effects of anticancer drugs, such as docetaxel (17-22), while the latter is classified as venous, due to deep vein thrombosis or return obstruction; lymphatic, lymph node swelling, or obstruction of lymphatic vessels; inflammatory due to celluli-

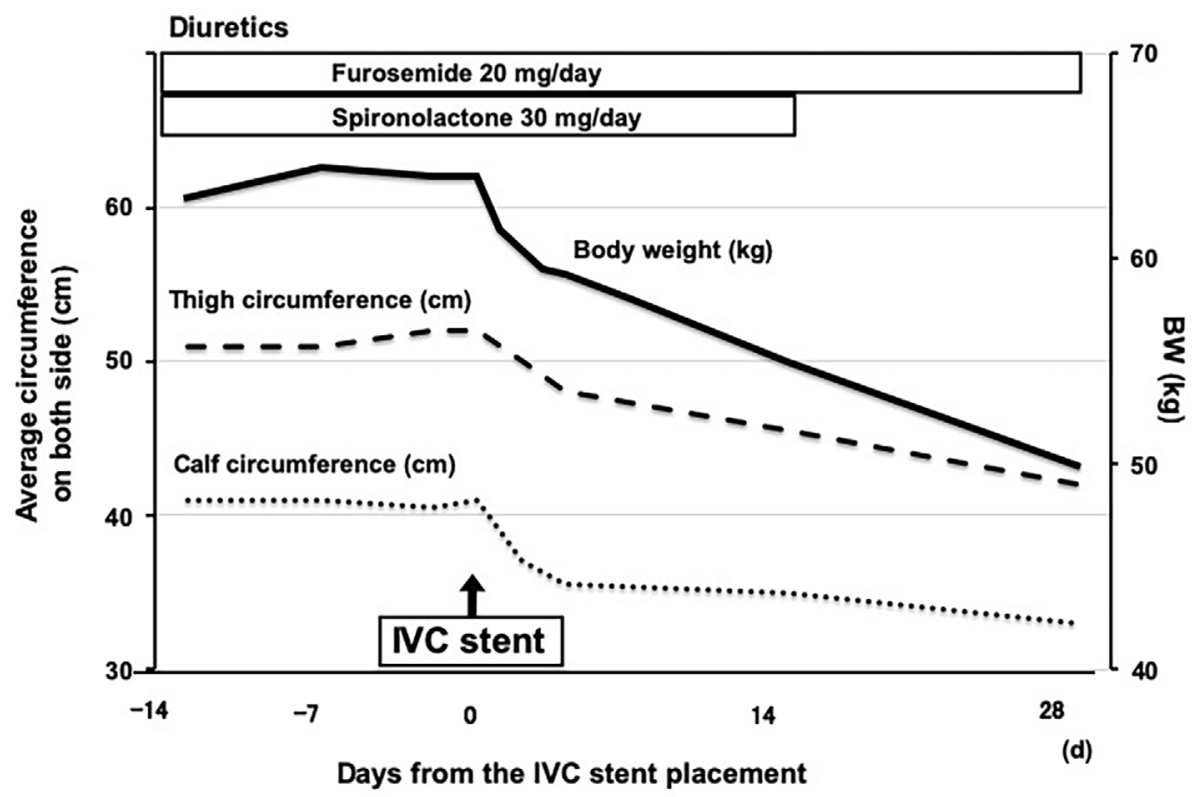

Figure 3. Changes in the body weight and the circumference of the thigh and calf after placement of the IVC stent. BW: body weight, IVC: inferior vena cava 
Table 2. Summary of Stent Placement for Malignant IVC Syndrome.

\begin{tabular}{|c|c|c|c|c|c|c|c|c|c|c|}
\hline No. & Reference & Study design & $\begin{array}{l}\text { No.of } \\
\text { patients }\end{array}$ & $\begin{array}{l}\text { Tumor type or } \\
\text { primary disease }\end{array}$ & $\begin{array}{l}\text { Technical } \\
\text { success }\end{array}$ & $\begin{array}{l}\text { Clinical } \\
\text { success }\end{array}$ & $\begin{array}{l}\text { Major adverse } \\
\text { events }\end{array}$ & Patency & $\begin{array}{l}\text { Anti- } \\
\text { coagulation } \\
\text { therapy }\end{array}$ & $\begin{array}{l}\text { Survival } \\
\text { time }\end{array}$ \\
\hline 1 & (10) & Case report & 1 & $\begin{array}{l}\text { Colon cancer } \\
\text { with multiple } \\
\text { liver metastases }\end{array}$ & Yes & Yes & No & $\begin{array}{c}19.5 \\
\text { months }\end{array}$ & Yes & $\begin{array}{c}19.5 \\
\text { months }\end{array}$ \\
\hline 2 & (30) & $\begin{array}{l}\text { Retrospective } \\
\text { study }\end{array}$ & 8 & $\begin{array}{l}\text { Five different } \\
\text { tumor types }\end{array}$ & $100 \%$ & $60 \%$ & Stent breakage 1 & N/A & N/A & $\begin{array}{c}3.0 \\
\text { months } \\
\text { (median) }\end{array}$ \\
\hline 3 & (31) & $\begin{array}{l}\text { Retrospective } \\
\text { study }\end{array}$ & 50 & $\begin{array}{l}\text { Primary liver } \\
\text { tumor } 9 \text {, } \\
\text { Metastatic liver } \\
\text { tumor } 41\end{array}$ & $100 \%$ & $86.4 \%$ & Stent migration 2 & $\begin{array}{l}92 \% \text { at } 3 \\
\text { months } \\
59 \% \text { at } 18 \\
\text { months }\end{array}$ & No & $\begin{array}{l}75 \text { days } \\
\text { (median) }\end{array}$ \\
\hline 4 & (9) & $\begin{array}{l}\text { Retrospective } \\
\text { study }\end{array}$ & 19 & $\begin{array}{l}\text { Primary liver } \\
\text { tumor } 3 \text {, } \\
\text { Metastatic liver } \\
\text { tumor } 15, \\
\text { Adrenal cancer } \\
\text { invasion for } \\
\text { IVC } 1\end{array}$ & $100 \%$ & $79 \%$ & $\begin{array}{c}\text { Stent compression } \\
2, \text { Stent migration } \\
1\end{array}$ & $\begin{array}{l}52.6 \% \\
\text { until } \\
\text { death }\end{array}$ & Yes & N/A \\
\hline 5 & (34) & $\begin{array}{l}\text { Retrospective } \\
\text { study }\end{array}$ & $\begin{array}{l}62 \text { (contain } \\
46 \text { cases of } \\
\text { benign } \\
\text { disease) }\end{array}$ & $\begin{array}{c}\text { Cancer } \\
\text { associated IVC } \\
\text { compression 16, } \\
\text { Others } 46\end{array}$ & $98 \%$ & $90 \%$ & $\begin{array}{c}\text { Stent occlusion } 13 \text {, } \\
\text { Stent stenosis } 10\end{array}$ & $\begin{array}{l}57 \% \text { at } 24 \\
\text { months }\end{array}$ & Yes & N/A \\
\hline 6 & (14) & $\begin{array}{l}\text { RCT, } \\
\text { prospective } \\
\text { study }\end{array}$ & $\begin{array}{l}44 \text { (contain } \\
25 \text { cases of } \\
\text { SVC } \\
\text { syndrome) }\end{array}$ & $\begin{array}{l}\text { Lung cancer 21, } \\
\text { Colorectal } \\
\text { cancer } 9, \\
\text { Breast cancer 2, } \\
\text { Others } 12\end{array}$ & $97.7 \%$ & $\begin{array}{l}\text { QOL score } \\
\text { significantly } \\
\text { improved } \\
\text { compared to } \\
\text { control } \\
\text { group }\end{array}$ & $\begin{array}{c}\text { Pulmonary } \\
\text { thromboembolism } \\
\text { 2, Dyspnea 1, } \\
\text { Hypotension } 1\end{array}$ & N/A & N/A & $\begin{array}{l}67 \text { days } \\
\text { (median) }\end{array}$ \\
\hline 7 & Our case & Case report & 1 & $\begin{array}{l}\text { Colon cancer } \\
\text { with abdominal } \\
\text { lymph node } \\
\text { metastases }\end{array}$ & Yes & Yes & No & $\begin{array}{l}7 \text { months } \\
\text { (patent) }\end{array}$ & Yes & $\begin{array}{l}7 \text { months } \\
\text { (alive) }\end{array}$ \\
\hline
\end{tabular}

IVC: inferior vena cava, SVC: superior vena cava, RCT: randomized controlled trial, QOL: quality of life, N/A: information not available

tis; and angioneurotic, occurring in an area paralyzed due to cerebral infarction.

In the case of lower body edema, it is important to distinguish between the lymphatic and venous forms $(17,23)$. Lymphedema can develop gradually after gynecological, rectal and prostate cancer surgery. Lymphedema is appeared non-pitting edema with no pain. Venous edema, by contrast, is a rapidly developing congestive condition causing distention (17). Due to the large amount of water stored in the interstitium, pitting edema appears.

Malignant vena cava syndrome is associated with the progression of tumors that compress or infiltrate the vessel, impairing blood flow and causing venous edema (1-3). IVC syndrome is caused by liver and retroperitoneal tumors and results in lower limb edema and intractable ascites (7-9). Consequently, the patient experiences lower limb pain, abdominal bloating, renal dysfunction, dysuria and other problems that significantly reduce the QOL. However, the symptoms of IVC syndrome are not necessarily life-threatening, and-unlike SVC syndrome-the condition is often followed with conservative treatment $(2,4-6)$.

Treatment of IVC syndrome essentially focuses on chemotherapy for the tumor and irradiation for the primary disease (24). This approach is particularly suited as a first-line treatment for highly sensitive tumors, such as malignant lymphoma and germ cell tumors. However, most patients must maintain an extended course of treatment if the cancers are refractory to chemotherapy, which can lead to a significant reduction in the performance status. Therefore, pharmacotherapy, such as diuretics and albumin preparations $(16,17,25)$, is generally complemented by physical therapy, such as massage and the use of compression stockings $(26,27)$. Collateral venous circulation may develop during follow-up of IVC syndrome, resulting in spontaneous relief of symptoms. In most cases, however, the symptoms do not improve despite long-term conventional treatment.

Vascular bypass is mainly used for vena cava syndrome resulting from a benign disease, but it is also performed for tumor resection in cases of venous invasion $(28,29)$. However, its degree of invasiveness for malignant vena cava syndrome caused by unresectable cancer is extremely high. The placement of a metal stent for vena cava syndrome has also been used for patients with malignant tumors, resulting in symptom improvement in $60-100 \%$ of cases $(4,7,9,10,14$, 30-33). Furthermore, stent placement has a low degree of physical invasiveness while achieving rapid and sustained symptom relief. Thus far, two case reports and five clinical studies, including our own, on malignant IVC syndrome 
treated with stent placement have been described, and their details are summarized in Table $2(9,10,14,30,31,34)$. The adverse events of IVC stent placement were reported to include a fever, pain, stent migration and sepsis. Pulmonary embolism was rare but life-threatening (14). The use of preoperative imaging to confirm the presence of thrombus in the vena cava was considered significant.

Symptom relapse due to stent occlusion has been reported $(9,33)$. The venous blood flow may become slow and stagnant; coagulation abnormalities resulting from malignant tumors tend to cause thrombotic stent blockage. Although it is desirable to perform anticoagulation therapy after stent placement (31-35), there is little evidence for its effectiveness. Furthermore, tumor invasion within the stent can result in occlusion due to ingrowth and thrombus attachment. Continuation of chemotherapy after stent placement may reduce tumor ingrowth, thus extending the period of stent patency. In the present case, direct oral anticoagulants were started after stent placement. In addition, the improvement in the patient's QOL with the IVC stent placement allowed chemotherapy to be resumed. No stent occlusion was evident during the first seven months of follow-up. Stent placement might improve the prognosis of cases with IVC syndrome.

Although further studies are necessary, the present case suggests that stent placement is feasible and effective for managing IVC syndrome and is not inferior to other treatments.

This case report was approved by the institutional Human Investigation Committee of Uonuma Institute of Community Medicine Niigata University Hospital. Written informed consent was obtained from the patient in accordance with the Helsinki declaration for publication of this case report.

The authors state that they have no Conflict of Interest (COI).

\section{References}

1. Charnsangavej $\mathrm{C}$, Carrasco $\mathrm{CH}$, Wallace $\mathrm{S}$, et al. Stenosis of the vena cava: preliminary assessment of treatment with expandable metallic stents. Radiology 161: 295-298, 1986.

2. Kishi K, Sonomura T, Mitsuzane K, et al. Self-expandable metallic stent therapy for superior vena cava syndrome: clinical observations. Radiology 189: 531-535, 1993.

3. Fletcher WS, Lakin PC, Pommier RF, Wilmarth T. Results of treatment of inferior vena cava syndrome with expandable metallic stents. Arch Surg 133: 935-938, 1998.

4. Tanigawa N, Sawada S, Mishima K, et al. Clinical outcome of stenting in superior vena cava syndrome associated with malignant tumors. Comparison with conventional treatment. Acta Radiol 39: 669-674, 1998.

5. Rowell NP, Gleeson FV. Steroids, radiotherapy, chemotherapy and stents for superior vena caval obstruction in carcinoma of the bronchus: a systematic review. Clin Oncol 14: 338-351, 2002.

6. Straka C, Ying J, Kong FM, Willey CD, Kaminski J, Kim DW. Review of evolving etiologies, implications and treatment strategies for the superior vena cava syndrome. Springerplus 5: 229, 2016.
7. Brountzos EN, Binkert CA, Panagiotou IE, Petersen BD, Timmermans H, Lakin PC. Clinical outcome after intrahepatic venous stent placement for malignant inferior vena cava syndrome. Cardiovasc Intervent Radiol 27: 129-136, 2004.

8. Kudo H, Yata Y, Orihara T, Kageyama M, Takahara T, Sugiyama T. Malignant inferior vena cava syndrome. Intern Med 45: 219220, 2006.

9. Kuetting D, Thomas D, Wilhelm K, Pieper CC, Schild HH, Meyer C. Endovascular management of malignant inferior vena cava syndromes. Cardiovasc Intervent Radiol 40: 1873-1881, 2017.

10. Sato Y, Inaba Y, Yamaura H, Takaki H, Arai Y. Malignant inferior vena cava syndrome and congestive hepatic failure treated by venous stent placement. J Vasc Intervent Radiol 23: 1377-1380, 2012.

11. Fagedet D, Thony F, Timsit JF, et al. Endovascular treatment of malignant superior vena cava syndrome: results and predictive factors of clinical efficacy. Cardiovasc Intervent Radiol 36: 140-149, 2013.

12. Steinberger J, Schenning R. Endovascular reconstruction of malignant IVC and SVC obstruction. Int Oncl 111-113, 2015.

13. Marmagkiolis K, Lendel V, Cilingiroglu M. Endovascular management of IVC syndrome after IVC filter placement. Rev Port Cardiol 34: 555.e551-e554, 2015.

14. Takeuchi Y, Arai Y, Sone M, et al. Evaluation of stent placement for vena cava syndrome: phase II trial and phase III randomized controlled trial. Support Care Cancer 27: 1081-1088, 2019.

15. Gospodarowicz CW. TMN Classification of Malignant Tumors (UICC). 8th ed. Wiley-Blackwell, New York, 2017.

16. O'Brien JG, Chennubhotla SA, Chennubhotla RV. Treatment of edema. Am Fam Physician 71: 2111-2117, 2005.

17. Trayes KP, Studdiford JS, Pickle S, Tully AS. Edema: diagnosis and management. Am Fam Physician 88: 102-110, 2013.

18. Siddall EC, Radhakrishnan J. The pathophysiology of edema formation in the nephrotic syndrome. Kidney Int 82: 635-642, 2012.

19. Navas JP, Martinez-Maldonado M. Pathophysiology of edema in congestive heart failure. Heart Dis Stroke 2: 325-329, 1993.

20. Sakaida I. Tolvaptan for the treatment of liver cirrhosis oedema. Expert Rev Gastroenterol Hepatol 8: 461-470, 2014.

21. Chaker L, Bianco AC, Jonklaas J, Peeters RP. Hypothyroidism. Lancet 390: 1550-1562, 2017.

22. Baker J, Ajani J, Scotte F, et al. Docetaxel-related side effects and their management. Eur J Oncol Nurs 13: 49-59, 2009.

23. Grada AA, Phillips TJ. Lymphedema: diagnostic workup and management. J Am Acad Dermatol 77: 995-1006, 2017.

24. Lepper PM, Ott SR, Hoppe H, et al. Superior vena cava syndrome in thoracic malignancies. Respir Care 56: 653-666, 2011.

25. Brater DC. Diuretic therapy. New Engl J Med 339: 387-395, 1998.

26. Partsch H, Flour M, Smith PC. Indications for compression therapy in venous and lymphatic disease consensus based on experimental data and scientific evidence. Under the auspices of the IUP. Int Angiol 27: 193-219, 2008.

27. Rabe E, Partsch H, Hafner J, et al. Indications for medical compression stockings in venous and lymphatic disorders: an evidence-based consensus statement. Phlebology 33: 163-184, 2018.

28. Alghulayqah A, Alghasab N, Amin T, Alkahtani N, Farhat R, Alzahrani AS. Long-term recurrence-free survival of adrenocortical cancer extending into the inferior vena cava and right atrium: case report and literature review. Medicine 96: e6751, 2017.

29. Kalra M, Sen I, Gloviczki P. Endovenous and operative treatment of superior vena cava syndrome. Surg Clin North Am 98: 321335, 2018.

30. Oudkerk M, Heystraten FM, Stoter G. Stenting in malignant vena caval obstruction. Cancer 71: 142-146, 1993.

31. Brountzos EN, Binkert CA, Panagiotou IE, Petersen BD, 
Timmermans H, Lakin PC. Clinical outcome after intrahepatic venous stent placement for malignant inferior vena cava syndrome. Cardiovasc Intervent Radiol 27: 129-136, 2004.

32. Okamoto D, Takeuchi $Y$, Arai $Y$, et al. Bridging stent placement through the superior vena cava to the inferior vena cava in a patient with malignant superior vena cava syndrome and an iodinated contrast material allergy. Jpn J Radiol 32: 496-499, 2014.

33. Bjarnason $H$. Tips and tricks for stenting the inferior vena cava. Semin Vasc Surg 26: 29-34, 2013.

34. Sebastian T, Dopheide JF, Engelberger RP, Spirk D, Kucher N. Outcomes of endovascular reconstruction of the inferior vena cava with self-expanding nitinol stents. J Vasc Surg Venous Lymphat
Disord 6: 312-320, 2018.

35. Sauter A, Triller J, Schmidt F, Kickuth R. Treatment of superior vena cava (SVC) syndrome and inferior vena cava (IVC) thrombosis in a patient with colorectal cancer: combination of SVC stenting and IVC filter placement to palliate symptoms and pave the way for port implantation. Cardiovasc Intervent Radiol 31: S144S148, 2008.

The Internal Medicine is an Open Access journal distributed under the Creative Commons Attribution-NonCommercial-NoDerivatives 4.0 International License. To view the details of this license, please visit (https://creativecommons.org/licenses/ by-nc-nd/4.0/).

(C) 2020 The Japanese Society of Internal Medicine Intern Med 59: 2885-2890, 2020 